\title{
STUDENTS RESPONSE TOWARD THE USE OF SCANNING TECHNIQUE IN READING RECOUNT TEXT
}

\author{
Yudi Lesmana ${ }^{1}$, Setya Resmini \\ ${ }^{1}$ IKIP Siliwangi \\ ${ }^{2}$ IKIP Siliwangi \\ ${ }^{1}$ ylesmana98@ student.ikipsiliwangi.ac.id, ${ }^{2}$ setyaresmini@ikipsiliwangi.ac.id
}

\begin{abstract}
The intention of these research is to know the students' responses toward the use of scanning technique in reading recount text. Scanning technique is either of alternative ways to reading especially in reading recount text because it could help students to easy to find the answer of the test with used multiple choice form, students will respond the question quickly. These research used descriptive qualitative method and the participant of these research was at an eighth grade of a Junior High School in Bandung. This research has been implemented by giving questionnaire consisted of positive and negative statements. The results shows that almost all of the students $(71.80 \%)$ agree that the use of scanning technique in reading on recount text becomes easy and they can understand the text well and fast and answering in a simple way.
\end{abstract}

Keywords: Reading, Recount Text, Scanning

\section{INTRODUCTION}

Reading is one of language skills, must be understood well by the students because reading is an important factor that affect one's activity in communication. Reading is considered as a decoding skill, that is deciphering codes into ideas. People considered reading as a key activity, thus the people usually said reading as the window of the world. By reading, people can receive the information widely without going anywhere.

Reading is either of English skills besides speaking, listening and writing. Those the way to understand written messages. (Ahmadi, 2013) also state that the reading strategy of cognitive aspect understanding ability to play an active role in education process. In addition, (Yunn in AydinBulut, 2017) states that a student activity in acting, arguing, and building meaning in the process before reading at the time of reading-after reading. (Parmawati, 2018) statetd that reading habits more clearly expresses the automatic and unconcious process that are involved in constructing meaning from text. Therefore, it can be deduced that reading is considered as a key activity in any language class.

Recount text is a text that retells a story as regards an event or past incident in the order in which they occur. The aim is to advise or retell past event and also give the audience some description of what and when occured. It retells past event for the aim of informing or entertaining. It could be experiences, life in the past, the history of something. (Anderson, 2003) states that recount is a piece of text that retells past events, usually in the order in which they occurred. As (Saragih, 2014) mention that, a recount is written out to inform an event or to comfort people. Recount text is text function as for advise an occurrence in the past. (Hyland, 2004) also said that recount is a type of genre that has social function to retell event for the purpose or entertaining. 
However, from the researcher experience when he was in teaching practice program (PLP), there are various difficulties faced by students. Students had the difficulties in reading because they not known what the content of the texts. Not only that, the students also did not know technique that they had to used when they are reading a text to get or to know the point of the text. Thus, from the result of test it made the students getting the low score because their weakness on reading.

To solve the problem, the researcher appllied scanning technique to find out the students' response in reading recount text. (Berszenyi, 2001) stated that reports various types of students responses when given feedback. They were revising words or sentences which were presented with an explanation ot students agreement toward the researcher suggestion or treatment of the text. Thus, can be assumed that scanning technique is a probably technique for the students to be weared in their reading. Scanning is very significant for finding a specific information or fact without reading the whole text. In scanning technique, readers must be compliant to skip most of part of text without reading or comprehending the text. According to (Rachmania, 2013) from the results of research scanning techniques proved to improve students' reading ability and can save time. Although the meaning of reading by scanning techniques is how to find the main information without wasted time.

The objective of scanning is to concentrate specific information sans reading through the entire text. The reader can use this strategy to spot for the detail information to the text such as looking for the names or dates, finding the content of a key concept, and listing a certain number of supporting details. It can be assumed that to find out the students' response in reading on recount text could be measured by using scanning technique.

\section{METHOD}

In this research the researcher desire to got the information about the students' response in reading recount text using scanning technique. This research was conducted at a Junior High School in Bandung. The participants of this research were students at an eighth grade of Junior High School in Bandung. The researcher giving questionnaire whether to find out the students response. The questionnaire consisted of positive and ngeative statements. In this case the researcher will use the design descriptive qualitative. A descriptive qualitative was employed in this research to inquiry the use of scanning technique in reading recount text. According to (Apsari, 2017) qualitative research is syntheticor holistic, heuristic, with little or no control and manipulation of the research content.

\section{RESULTS AND DISCUSSION}

\section{Results}

The researcher was conducted by giving questionnaire. The questionnaire consisted of eight positive and two negative statement. The researcher applied the scanning technique in reading recount text, the teacher conducted the researcher in the one of class based on the problems in an eighth grade of Junior High School in Bandung. In order to find out the students response toward the use of scanning technique in reading recount text. The researcher observed the teaching process of VIII A class. There were 32 students in VIII A class. The researcher classified the students' answer of questionnaire form to know the correct number of the student's answer in the questionnaire sheets. From these data, the researcher knew the students' opinion. 
The researcher used (Masidjo, 1995) standard in reading.

Table 1. Criteria of Reading

\begin{tabular}{cl}
\hline Range & Qualification \\
\hline $90-100$ & Excellent \\
$80-89$ & Very good \\
$65-79$ & Good \\
$55-64$ & Sufficient \\
Less than 55 & Insufficient \\
\hline
\end{tabular}

After collecting the student questionnaire sheets, the researcher calculates the students' response in order to got their opinion. The results of several questions can be visible from the table below

Table 2. Result of Questionnaire Data Analysis

\begin{tabular}{ccccc}
\hline $\begin{array}{c}\text { Question } \\
\text { number }\end{array}$ & YES & \% & NO & $\%$ \\
\hline 1 & 22 & $68,75 \%$ & 7 & $21 \%$ \\
\hline 2 & 29 & $90 \%$ & 0 & $0 \%$ \\
\hline 3 & 5 & $15,60 \%$ & 24 & $75 \%$ \\
\hline 4 & 18 & $56 \%$ & 11 & $34,30 \%$ \\
\hline 5 & 26 & $81,20 \%$ & 3 & $9,30 \%$ \\
\hline 6 & 28 & $87,50 \%$ & 1 & $3,10 \%$ \\
\hline 7 & 25 & $78,10 \%$ & 4 & $12,50 \%$ \\
\hline 8 & 14 & $43,75 \%$ & 15 & $46, \%$ \\
\hline 9 & 23 & $71,80 \%$ & 6 & $18,75 \%$ \\
\hline 10 & 22 & $68,75 \%$ & 7 & $21, \%$ \\
\hline
\end{tabular}

The students' response toward the use of scanning technique in reading recount text, it can be seen that students generally like in learning recount text because they can increase their knowledge, know many stories and some students said that learning recount text is important retell the past story or event. The result shows that almost all of the students $(71.80 \%)$ agree that learning recount text with scanning technique becomes easy and they can understood the text well and fast and answering in a simple way. The students also get benefits because with scanning technique the students are competent to got the information quickly, directly, and specifically.

\section{Discussion}

This part covers the discussion of the students' responses toward the use of scanning. The researcher discussed the result from the data analysis of the questionnaire sheets in compliance with the scope of this research. The discussion is intended to find out the students response toward the use of scanning technique in reading recount text. From the results of these research, most of the students have improvement in their learning of recount text. The students that have problem in responding multiple choice and wasting much time to read, can improve their understanding better. Thus, the students get many benefits in applying scanning technique in 
reading recount text. By using scanning technique, students can encourage to know some new way in reading.

\section{CONCLUSION}

The students' responses toward the use of scanning technique in reading recount text at an eighth grade in Junior High School in Bandung have a good response. The findings shows that almost all of the students $(71.80 \%)$ agree that learning recount text with scanning technique becomes easy and they can understood the text well and fast and answering in a simple way. Thus, the scanning technique is either of alternative ways to reading especially in reading recount text because it can contribute students to easy to find the answer of the test with used multiple choice form, students will respond the question quickly.

\section{ACKNOWLEDGMENTS}

All praise goes to Allah S.W.T who has given us grace and affection. As well as giving us the opportunity to complete this research. These research was supported by our campus IKIP Siliwangi, our beloved lecturers who always give us their guidance and knowledge and also our beloved family and friends. The researcher are thankful to your support in the writing process of this research. And also to the Mrs. Nendah Rubiatin Pebriah as English teacher at Junior High School in Bandung which has allowed me to carry out this journal research.

The researcher are also grateful to Mrs. Setya Resmini, M.Pd who always give me her guidance and help to write this research. The researcher have to express out appreciation to all who have been involved in reading and publishing this research, for their comments on an earlier versions of the manuscript.

\section{REFERENCES}

Ahmadi. (2013). The Importance of Metacognitive Reading Strategy Awareness in Reading Comprehension. Canadian Center of Science and Education. Canadian Center of Science and Education, Vol.06.

Anderson, M. K. A. (2003). Text Type in English 3. McMillan Education PTY LTD.

Apsari, Y. (2017). The Use of Picture Series in Teaching Writing Recount Text. ELTIN JOURNAL, Journal of English Language Teaching in Indonesia, 5(2).

Berszenyi, C. A. (2001). Comments to Comments: Teachers and Students in Written Dialogue about Critical Revision. Http;//Www.Findarticles.Com/p/Articles/Mi Qa3986/15 200110/Ai $n$ 896744, Accesed on July 6, 2020.

Hyland, K. (2004). Genre and second Language Writing. The United State of America: The University of Michigan Press.

Masidjo, I. (1995). Penilaian pencapaian hasil belajar siswa disekolah. Walter de Gruyter, 153. Parmawati, A. (2018). The Study Correlation Between Reading Habit And Pronunciation Ability At The Second Grade Students Of Ikip Siliwangi. Eltin Journal, Journal Of English Language Teaching In Indonesia, 6(1), 46-52.

Rachmania. (2013). The effectivenessof Scanning Technique in Increasing Students' Reading Comprehension Achievement. Http://Download.Portalgaruda.Org/Article.Php Retrieved on Maret 25, 2020.

Saragih, N. (2014). The Effectiveness of Using Recount Text to Improve Writing Skill for 
Grade III Students of Kalam Kudus Elementary School 2 Pematangsiantar. IOSR Journal Of Humanities and Social Science (IOSRJHSS), 19(1).

Yunn in AydinBulut. (2017). Improving 4thGrade Primary School Students' Reading Comprehension Skills. Universal Journal of Educational Research. 